\title{
Quantification of Bone Histomorphometric Parameters Using the Weibel Technique in Animals
}

\author{
SAIF AM ${ }^{1}$, NORAZLINA $M^{2}$, IMA-NIRWANA $S^{2}$ \\ ${ }^{1}$ Department of Anatomy and Cell Biology, School of Dental Medicine, University of \\ Pennsy/vania, Philadelphia, Pennsylvania 19104, United States of America. \\ ${ }^{2}$ Department of Pharmacology, Faculty of Medicine, Universiti Kebangsaan Malaysia \\ Medical Centre, Jalan Yaacob Latif, Bandar Tun Razak, 56000 Cheras, Kuala Lumpur, \\ Malaysia.
}

\begin{abstract}
ABSTRAK
Pengukuran histomorfometri tulang diperlukan untuk memahami kesan penyakit tulang dan juga keberkesanan rawatan pada metabolisme tulang dalam satu tempoh masa. Kajian sebelum ini menggunakan teknik Weibel sebagai kaedah stereologikal kuantitatif untuk menentukan perubahan sel dan dinamik tulang. Walau bagaimanapun, tidak ada penerangan tentang bagaimana teknik ini telah digunakan. Kajian ini bertujuan untuk memberikan gambaran lengkap tentang penggunaan teknik Weibel untuk mengukur indeks histomorfometri tulang statik dan dinamik. Kepakaran teknikal, pemprosesan optimum sampel tulang, perawakan hirisan tisu trabekular dan jumlah imej teranalisa yang mencukupi untuk setiap bahagian adalah diperlukan untuk mencapai keputusan yang boleh dipercayai dengan kemungkinan ralat yang rendah.
\end{abstract}

Kata kunci: histomorfometri tulang, pembentukan semula tulang, teknik Weibel

\begin{abstract}
Bone histomorphometric measurements are required to understand the efficacy of treatment on bone remodelling. Previous studies used the Weibel technique as a quantitative stereological method to determine bone cellular and dynamic changes. However, there was no description on how this technique was applied. This studyaimed to provide a full picture about the utilization of the Weibel technique to measure static and dynamic bone histomorphometric indices. Technical expertise, processing of bone samples, randomization of the trabecular sections and an adequate number of analysed images for each section are required
\end{abstract}

Address for correspondence and reprint requests: Ima-Nirwana Soelaiman, Department of Pharmacology, Faculty of Medicine, Universiti Kebangsaan Malaysia Medical Centre, Jalan Yaacob Latif, Bandar Tun Razak, 56000 Cheras, Kuala Lumpur, Malaysia. Tel: +603-91459579 Fax: +603-91456634 Email: imasoel@medic. ukm.my 
to achieve reliable results with a low possibility of errors.

Keywords: bone histomorphometry, bone remodelling, weibel technique

Bone is a unique dynamic tissue whereby its components undergo continuous resorption and redeposition by a process known as bone remodelling. Bone remodelling is a lifelong process which starts from the very earliest foetal bone formation and continues until death. In brief, this process involves the breakdown of mature bone (bone resorption) by osteoclasts and the activation of osteoblasts to build new bones (bone formation). Therefore, bone remodelling is a result of osteoclasts and osteoblasts activities (Abdul-Majeed et al. 2013). Bone resorption and formation are balanced in a homeostatic equilibrium to continuously replace old bones by new ones and to guarantee that there is no net loss or gain of bone; this coordinated balance is called coupling. The primary function of bone remodelling is to maintain bone health. However, uncoupling leads to unbalanced bone remodelling process and results in serious bone diseases like osteoporosis (Abdul-Majeed et al. 2015).

Bone histomorphometry is a quantitative method to obtain information on the process of bone remodelling at the level of the basic multicellular units. Static bone histomorphometry is used to examine bone histology and quantitatively evaluate the activity of bone cells at a specific time. Bone is a dynamic organ. Therefore, dynamic bone histomorphometry is the standard method for evaluating changes in cellular activity and bone remodelling over time (Vedi \& Compston 2003; Kulak \& Dempster 2010).

The Weibel technique is a quantitative stereological method for morphometric cytology and utilizes the M42 grid which is also known as a multipurpose test-system. Moreover, it can generate quantitative data on the internal structure of cell, tissue and organ (Weibel et al. 1966; Freere \& Weibel 1967).

Several preclinical studies had used the Weibel technique to determine static and dynamic bone histomorphometric parameters in intact rat and osteoporotic rats. Moreover, these studies used this technique to investigate the efficacy of antiosteoporotic therapies (Nazrun et al. 2005; Shuid et al. 2007; Hermizi et al. 2009; Mehat et al. 2010; Hermizi et al. 2011; Aktifanus et al. 2012; Fathilah et al. 2012; Hussan et al. 2012; Muhammad et al. 2012; Soelaiman et al. 2012; Abdul-Majeed et al. 2012; Chin et al. 2014; Parvaneh et al. 2015). These studies have referred to (Weibel et al. 1966; Freere \& Weibel 1967) in performing the protocol without a detailed description on how did they evaluate the parameters. Therefore, the aim of this paper is to provide a solid reference for those who will be doing the same analysis.

In this present paper, we describe the utilization of the Weibel 
technique to measure static and bone histomorphometric indices. Processing of decalcified and undecalcified bone sample is also discussed. In this brief technical report, the trabecular bone of rat femora was used to describe the technique. However, this technical report may be applied to other types of bone.

\section{PROCESSING OF BONE SAMPLES}

Three adult Sprague Dawley rats were purchased from the Laboratory Animal Research Unit, Universiti Kebangsaan Malaysia. The rats were kept two per cage under 12 hrs light-dark cycles. The rats were fed commercial rat chow and tap water ad libitum. After one week of acclimatization, the rats were sacrificed and the left femur of each rat was dissected out and cleaned of soft tissue. It was fixed in $70 \%$ alcohol for at least $72 \mathrm{hrs}$ and the distal third was divided sagittally using bone cutting tools with a low-speed saw. The first half was decalcified and stained with haematoxylin and eosin for static bone histomorphometric analysis while the second half was processed for dynamic histomorphometric analysis (Figure 1-4). The study protocol was obtained from the UKM Animal Ethics Committee, (PP/FAR/2011/IMA/27-JANUARY/352JANUARY-2011-DECEMBER-2012).

\section{PRINCIPLES AND GENERAL CONSIDERATION OF WEIBEL TECHNIQUE}

The stereological test system is composed of line system (21 lines) and point system (42 points) standards which are the basis for applying the principles of stereology. The line system represents the surface measurements while the point system reflects the volume measurement (Figure 5). The M42 grid was adjusted on the captured image and the parameters were calculated based on the Freere \& Weibel (1967) formulas. The computed values were obtained in ratio or percentage.

i) The relative surface area (Sa) was calculated as follows:

$$
\mathrm{Sa}=2 \mathrm{~N} / \mathrm{Lt}
$$

$\mathrm{N}=$ number of interactions between the test line and the surface of interest $\mathrm{Lt}=$ total number of the lines (21)

ii) The relative volume (V) was calculated as follows:

$$
\mathrm{V}=\mathrm{P} / \mathrm{Pt}
$$

$\mathrm{P}=$ number of interactions between the points and the surface of interest $\mathrm{Pt}=$ total number of points (42)

\section{QUANTIFICATION OF BONE CELLULAR HISTOMORPHOMETRY USING WEIBEL TECHNIQUE}

Bone static histomorphometric parameters that were measured using the Weibel technique are osteoblast surface/bone surface (ObS/BS \%), osteoclast surface / bone surface (OcS/ BS \%), eroded surface/bone surface (ES/BS \%), osteoid surface/bone surface (OS/BS \%) and osteoid volume/bone volume (OV/BV \%) (Figure 6-7; Table 1). 


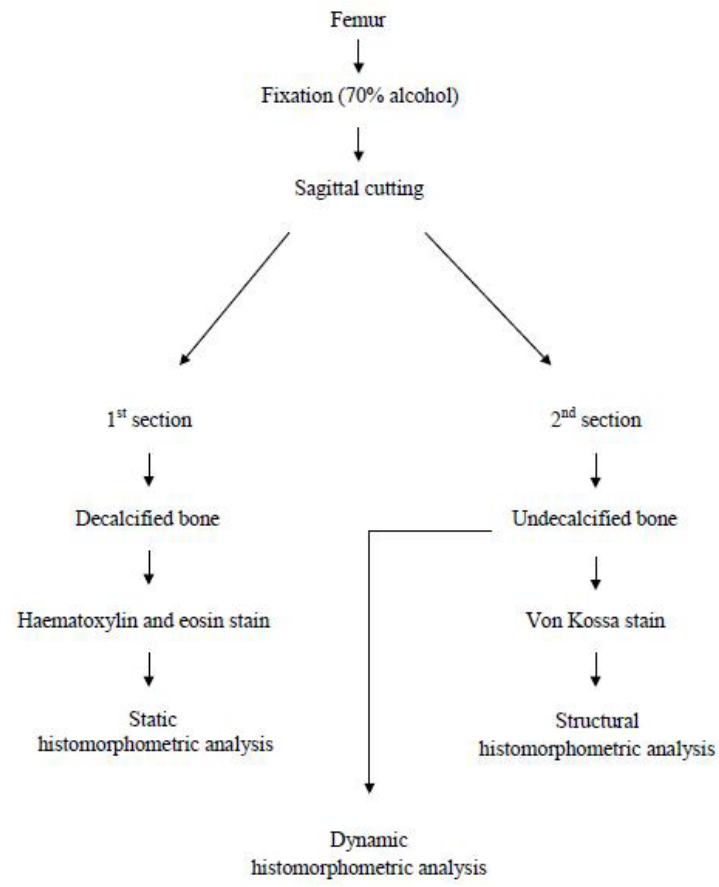

Figure 1: General protocol for bone histomorphometric analysis.

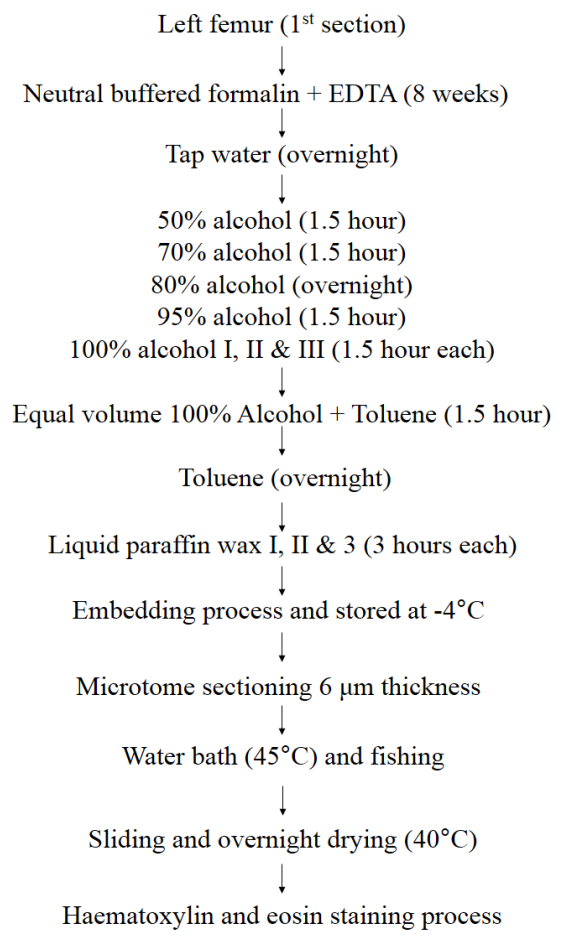

Figure 2: Processing of decalcified bone samples 


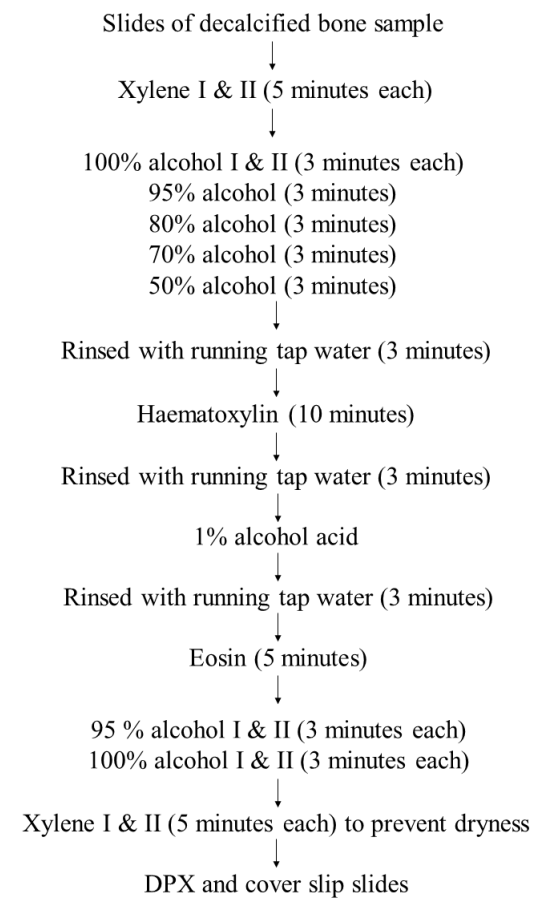

Figure 3: Haematoxylin and eosin staining protocol

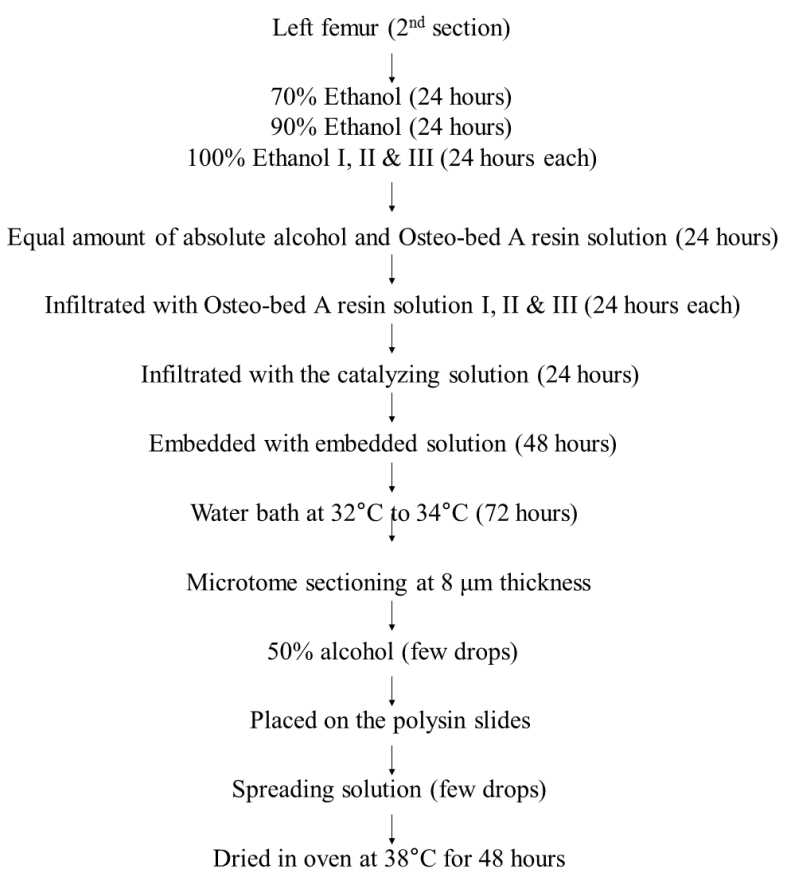

Figure 4: Processing of undecalcified bone samples 


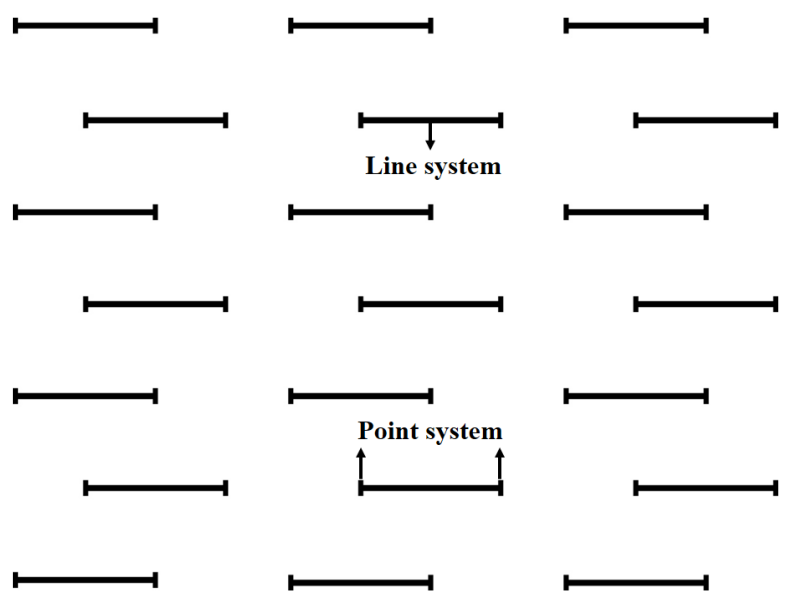

Figure 5: The Weibel grid composed of line system (21 lines) and point system (42 points)

i) Osteoblast Surface / Bone Surface (ObS/BS)

$$
\begin{aligned}
O b S / B S & =\frac{2 N L O b / \text { Lt (osteoblast) }}{2 N L T b / \text { Lt (trabecularbone) }} \\
& =\frac{2 N L O b / \text { tosteoblast) }}{2 N L T b / \text { trabecularbone) }} \\
& =\frac{N L O b \text { (osteoblast) }}{\text { NLTb (trabecularbone) }}
\end{aligned}
$$

$\mathrm{NLOb}=$ number of interactions between test lines and osteoblast cells $\mathrm{NLTb}=$ number of interactions between test lines and trabecular bones

ii)Osteoclast Surface/Bone Surface (OcS/BS)

$$
\begin{aligned}
O C S / B S= & \frac{2 N L O c / \text { Lt (osteoclast) }}{2 N L T b / \text { Lt (trabecularbone) }} \\
& =\frac{2 N L O c / \text { (osteoclast) }}{2 N L T b / \text { trabecularbone) }} \\
& =\frac{N L O C \text { (osteoclast) }}{\text { NLTb (trabecularbone) }}
\end{aligned}
$$

NLOc=number of interactions between test lines and osteoclast cells
$\mathrm{NLTb}=$ number of interactions between test lines and trabecular bones

iii) Eroded Surface / Bone Surface (ES/ BS)

$$
\begin{aligned}
E S / B S & =\frac{2 N L E S / \text { Lt (erodedsurface })}{2 N L T b / \text { Lt (trabecularbone) }} \\
& =\frac{2 N L E S / \text { terodedsurface })}{\fallingdotseq N L T b / \text { trabecularbone })} \\
& =\frac{\text { NLES (erodedsurface })}{\text { NLTb (trabecularbone) }}
\end{aligned}
$$

NLES=number of interactions between test lines and eroded surfaces $\mathrm{NLTb}=$ number of interactions between test lines and trabecular bones

iv) Osteoid Surface/Bone Surface (OS/ $\mathrm{BS})$

$$
\begin{aligned}
O S / B S & =\frac{2 N L O / L t \text { (osteoid) }}{2 N L T b / \text { Lt (trabecularbone) }} \\
& =\frac{2 N L O / \text { t (osteoid) }}{\text { ONLTb } / \text { trabecularbone) }} \\
& =\frac{N L O \text { (osteoid) }}{N L T b \text { (trabecularbone) }}
\end{aligned}
$$




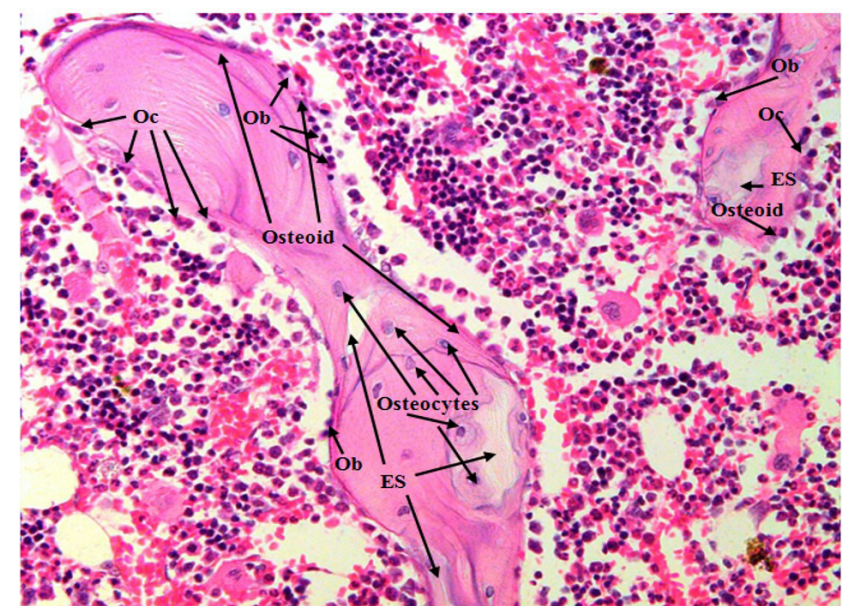

Figure 6: Micrographic photos of decalcified trabecular bone stained with haematoxylin and eosin (20x magnification) demonstrating cellular bone histomorphomertic parameters. Oc, osteoclast; $\mathrm{Ob}$, osteoblast; and ES, eroded surfaces.

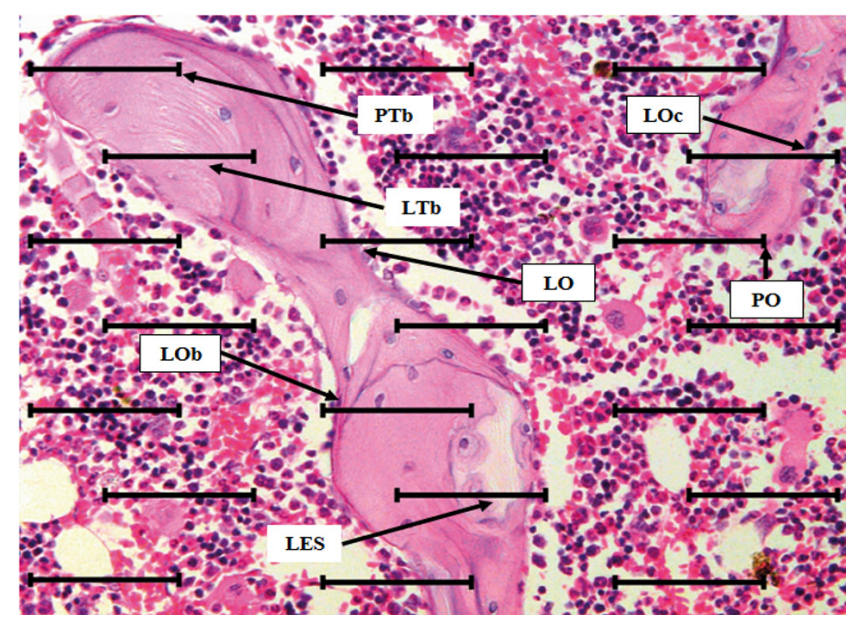

Figure 7: Sample of trabecular section stained with haematoxylin and eosin (20x magnification superimposed with multipurpose test-system (M42 grid). LTb, area of interaction between trabeculae and the test line; PTb, area of interaction between trabeculae and the test point; LOb, area of interaction between osteoblast cell and test line; LOc, area ofinteraction between osteoclast cell and test line; LES, area of interaction between eroded surface and test line; LO, area of interaction between osteoid and test line; PO, area of interaction betweenosteoid and test point.

Table 1: Description of bone static histomorphometric parameters

\begin{tabular}{lcc}
\hline \multicolumn{1}{c}{ Parameter } & Symbol & Unit \\
\hline Osteoblast surface / bone surface & ObS / BS & $\%$ \\
Osteoclast surface / bone surface & OcS / BS & $\%$ \\
Eroded surface / bone surface & ES / BS & $\%$ \\
Osteoid surface / bone surface & OS / BS & $\%$ \\
Osteoid volume / bone volume & OV / BV & $\%$ \\
\hline
\end{tabular}


$\mathrm{NLO}=$ number of interactions between test lines and osteoids

$\mathrm{NLTb}=$ number of interactions between test lines and trabecular bones

v) Osteoid Volume/Bone Volume (OV/ $\mathrm{BV})$

$$
\begin{aligned}
& O V / B V=\frac{2 N P O / P t \text { (osteoid })}{2 N P T b / \text { Pt }(\text { trabecularbone })} \\
& =\frac{2 N P O / P *(\text { osteoid })}{2 N P T b / P *(\text { trabecularbone })} \\
& =\frac{N P O(\text { osteoid })}{r b(\text { trabecularbone })}
\end{aligned}
$$

$\mathrm{NPO}=$ number of interactions between points and osteoid

$\mathrm{NPTb}=$ number of interactions between points and trabecular bones

\section{QUANTIFICATION OF BONE CELLULAR HISTOMORPHOMETRY USING WEIBEL TECHNIQUE}

In order to quantify the dynamic histomorphometric parameters the femurs need to be fluorescent-labelled with intraperitoneal injections of $20 \mathrm{mg} /$ $\mathrm{kg}$ calcein at day 9 and day 2 before the rats were sacrificed.

Bone dynamic histomorphometric parameters that were used as example are single-labelled surface/bone surface (sLS/BS \%), double-labelled surface/bone surface (dLS/BS \%), mineralizing surface/bone surface (MS/BS \%), mineral apposition rate (MAR $\mu \mathrm{m} /$ day) and bone formation rate (BFR $\mu \mathrm{m}^{3} / \mu \mathrm{m}^{2} /$ day) (Figure 8 , Table 2). Only sLS/BS \% and dLS/BS \% will be calculated by using the M42 grid while the rest of the parameters will be derived (Figure 9).

Single-labelled surface is formed after the first calcein injection (at day 9 before sacrifice) while the doublelabelled surface is formed after the second calcein injection (at day 2 before sacrifice). Double-labelled surface is darker than single-labelled surface. In general, sLS/BS parameter corresponds to poor bone formation while dLS/BS, MS/BS and MAR correspond to bone formation and mineralization.

i) Single-labelled surface/bone surface (sLS/BS)

$$
\begin{aligned}
& s L S / B S=\frac{2 N L s L S / L t(\text { single-labelled surface })}{2 N L T b / \text { Lt (trabecular bone })} \\
& =\frac{\frac{2 N L s L S / \text { tt }(\text { single-labelled surface })}{2 N L T b / \text { to (trabecular bone })}}{N L T b \text { (trabecularbone) }} \\
& =\frac{N L s L \text { (single-labelled surface })}{N}
\end{aligned}
$$

NLsLS=number of interactions between test lines and single-labelled surfaces $\mathrm{NLTb}=$ number of interactions between test lines and trabecular bones

ii) Double-labelled surface/Bone Surface (dLS/BS)

$$
\begin{aligned}
& d L S / B S=\frac{2 N L d L S / L t(\text { double-labeledsurface })}{2 N L T b / \text { Lt }(\text { trabecularbone })} \\
& =\frac{2 N L d L S / \text { to }(\text { double-labelledsurface })}{=N L T b / \text { trabecularbone })} \\
& =\frac{N L d L S \text { (double-labelledsurface) }}{\text { N }} \\
& \text { NLTb (trabecularbone) }
\end{aligned}
$$

NLdLS=number of interactions between test lines and double-labeled surfaces

$\mathrm{NLTb}=$ number of interactions between test lines and trabecular bones 
iii) Mineralizing Surface / Bone Surface (MS / BS)

$$
M S / B S=(s L S+1 / 2 d L S) / B S
$$

iv) Mineral Apposition Rate (MAR)

$$
M A R=X / Y
$$

$X=$ the distance between the two labels $\mathrm{Y}=$ days between the two calcein injections (7 days)

v) Bone Formation Rate/Bone Surface (BFR/BS)

$$
\mathrm{BFR} / \mathrm{BS}=(\mathrm{MS} / \mathrm{BS}) * \mathrm{MAR}
$$

MS/BS=mineralizing surface $M A R=$ mineral apposition rate

A vast amount of literature showed that the use of the Weibel technique is a very effective stereological test system and give reliable results on the analysis of bone static and dynamic histomorphometric parameters (Nazrun et al. 2005; Shuid et al. 2007; Hermizi et al. 2009; Mehat et al. 2010; Hermizi et al. 2011; Aktifanus et al. 2012; Fathilah et al. 2012; Hussan et al. 2012; Muhammad et al. 2012; Soelaiman et al. 2012; Abdul-Majeed et al. 2012; Chin et al. 2014; Parvaneh et al. 2015). However, a detailed description of the protocol had not been mentioned. According to our knowledge this is the first technical paper describes the implementation of Weibel technique in the assessment of bone histomorphometric indices.

However, there are several types of errors that might lead to false results such as processing of bone samples, the distribution of parameter of interest over the trabecular and the identification of each parameter of interest in the trabecular sections. Fixation of bone samples, thickness of trabecular sections and standardized staining protocol are the errors that affecting the quality of the of bone samples. Optimized technical skills could overcome the errors that might occur during the processing of bone samples (Weibel et al. 1966). Errors due to distribution of the parameter of interest over the trabecular bone can be overcome by randomizing the trabecular sections of each bone sample and quantifying at least three images for each trabecular section. Understanding the mechanism of bone metabolism can achieve good identification of parameter of interest. However, this method can easily be applied to bone histomorphometric measurements at the microscopic levels. This paper was not designed to compare this technique with other techniques.

A combination of bone histomorphometric measurements with the assessment of bone mineral density, micro computed tomography, bone radiography, serum levels of biochemical markers and histochemical measurements might give a better overall indication about bone health status and may be useful to predict the risk of fractures.

\section{ACKNOWLEDGMENT}

The authors would like to acknowledge Universiti Kebangsaan Malaysia for providing research grants FF-0732011 and UKM-DLP-2011-047 to conduct the current work. The authors 


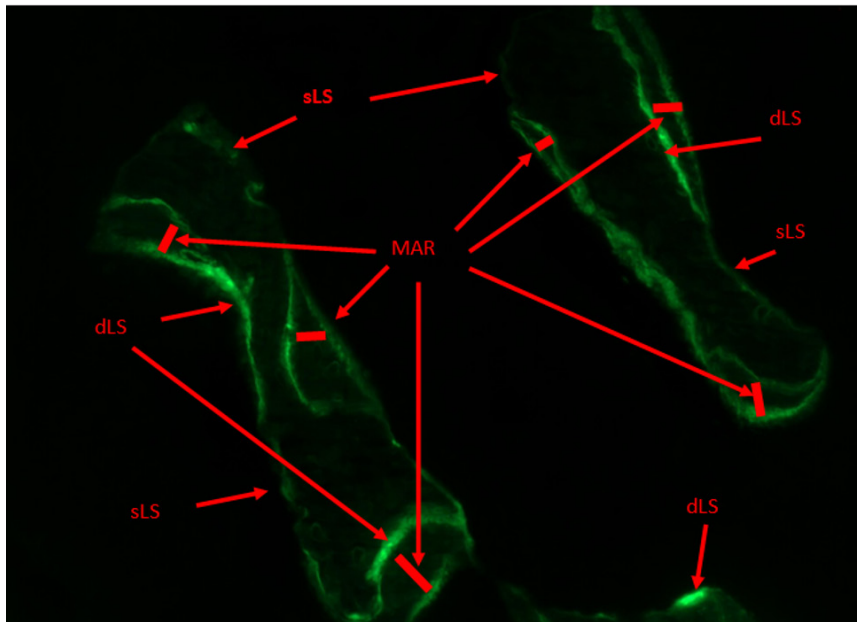

Figure 8: Micrographic photo of decalcified trabecular labelled with calcein (20x magnification) demonstrating dynamic bone histomorphometric parameters. dLS, double-labelled surface; sLS, single-labelled surface; MAR, mineral apposition rate.

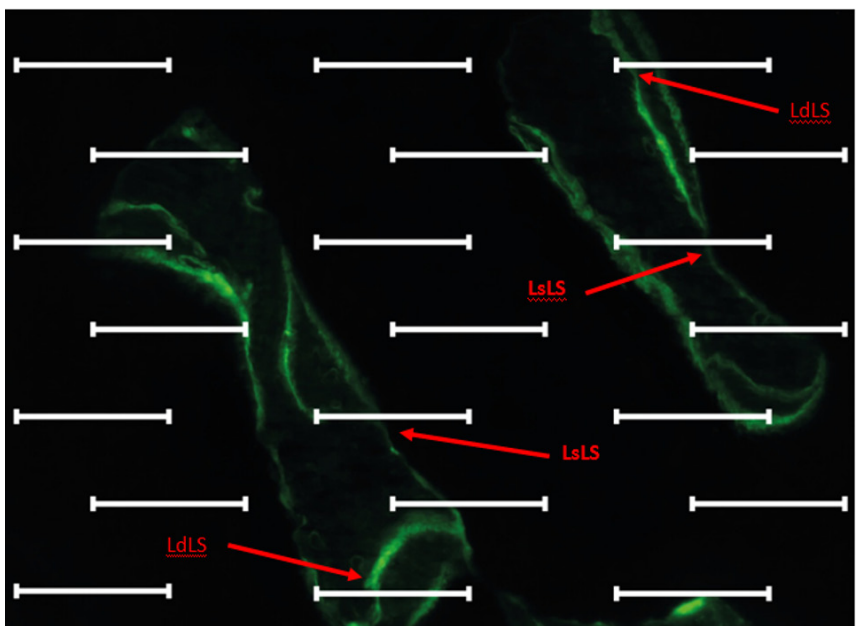

Figure 9: Sample of trabecular section labelled with calcein (20x magnification superimposed with multipurpose test-system (M42 grid). LsLS, area of interaction between single-labelled surface and test line; LdLS, area of interaction between double-labelled surface and test.

Table 2: Description of bone dynamic histomorphometric parameters

\begin{tabular}{lcc}
\hline \multicolumn{1}{c}{ Parameter } & Symbol & Unit \\
\hline Single-labeled surface / bone surface & $\mathrm{sLS} / \mathrm{BS}$ & $\%$ \\
Double-labeled surface / bone surface & $\mathrm{dLS} / \mathrm{BS}$ & $\%$ \\
Mineralizing surface / bone surface & $\mathrm{MS} / \mathrm{BS}$ & $\%$ \\
Mineral apposition rate & $\mathrm{MAR}$ & $\mathrm{m} /$ day \\
Bone formation rate/ bone surface & $\mathrm{BFR} / \mathrm{BS}$ & $\mathrm{m}^{3} / \mathrm{m}^{2} /$ day \\
\hline
\end{tabular}


like to thank the Department of Pharmacology, Faculty of Medicine, Universiti Kebangsaan Malaysia for the technical support and laboratory facilities to conduct this study.

\section{REFERENCES}

Abdul-Majeed, S., Mohamed, N., Soelaiman, I.N. 2012. Effects of tocotrienol and lovastatin combination on osteoblast and osteoclast activity in estrogen-deficient osteoporosis. Evid Based Complement Alternat Med 2012: 960742.

Abdul-Majeed, S., Mohamed, N., Soelaiman, I.N. 2013. A review on the use of statins and tocotrienols, individually or in combination for the treatment of osteoporosis. Curr Drug Targets 14(13): 1579-90.

Abdul-Majeed, S., Mohamed, N., Soelaiman, I.N. 2015. The use of delta-tocotrienol and lovastatin for anti-osteoporotic therapy. Life Sci 125: 42-8.

Aktifanus, A.T., Shuid, A.N., Rashid, N.H.A., Ling, T.H., Loong, C.Y., Saat, N.M., Muhammad, N., Mohamed, N., Soelaiman, I.N. 2012. Comparison of the effects of tocotrienol and estrogen on the bone markers and dynamic changes in postmenopausal osteoporosis rat model. Asian J Anim Vet Adv 7(3): 225-34.

Chin, K.Y., Abdul-Majeed, S., Fozi, N.F., ImaNirwana, S. 2014. Annatto tocotrienol improves indices of bone static histomorphometry in osteoporosis due to testosterone deficiency in rats. Nutrients 6(11): 4974-83.

Fathilah, S.N., Nazrun Shuid, A., Mohamed, N., Muhammad, N., Nirwana Soelaiman, I. 2012. Labisia pumila protects the bone of estrogendeficient rat model: a histomorphometric study. J Ethnopharmacol 142(1): 294-9.

Freere, R.H., Weibel, E.R. 1967. Stereologic techniques in microscopy. J $R$ Microsc Soc 87(1): 25-34.

Hermizi, H., Faizah, O., Ima-Nirwana, S., Ahmad Nazrun, S., Norazlina, M. 2009. Beneficial effects of tocotrienol and tocopherol on bone histomorphometric parameters in spraguedawley male rats after nicotine cessation. Calcif Tissue Int 84(1): 65-74.

Hermizi, H., Faizah, O., Ima-Nirwana, S., Ahmad Nazrun, S., Luke, D.A., Norazlina, M. 2007. Nicotine impaired bone histomorphometric parameters and bone remodelling biomarkers in Sprague-Dawley male rats. Ann MicrosC 7: 10-24.

Hussan, F., Ibraheem, N.G., Kamarudin, T.A., Shuid, A.N., Soelaiman, I.N., Othman, F. 2012. Curcumin Protects against OvariectomyInduced Bone Changes in Rat Model. Evid Based Complement Alternat Med 2012: 174916.

Kulak, C.A., Dempster, D.W. 2010. Bone histomorphometry: a concise review for endocrinologists and clinicians. Arq Bras Endocrinol Metabo/ 54(2): 87-98.

Mehat, M.Z., Shuid, A.N., Mohamed, N., Muhammad, N., Soelaiman, I.N. 2010. Beneficial effects of vitamin $\mathrm{E}$ isomer supplementation on static and dynamic bone histomorphometry parameters in normal male rats. J Bone Miner Metab 28(5): 503-9.

Muhammad, N., Luke, D.A., Shuid, A.N., Mohamed, N., Soelaiman, I.N. 2012. Two different isomers of vitamin $\mathrm{E}$ prevent bone loss in postmenopausal osteoporosis rat model. Evid Based Complement Alternat Med 2012: 161527.

Nazrun, A.S., Luke, D.A., Khalid, B.A.K., ImaNirwana, S. 2005. Vitamin E protects from freeradical damage on femur of rats treated with ferric nitrilotriacetate. Curr Top Pharmaco/ 9(2): 107-15.

Parvaneh, K., Ebrahimi, M., Sabran, M.R., Karimi, G., Hwei, A.N., Abdul-Majeed, S., Ahmad, Z., Ibrahim, Z., Jamaluddin, R. 2015. Probiotics (bifidobacterium longum) increase bone mass density and upregulate SPARC and BMP-2 genes in rats with bone loss resulting from ovariectomy. Biomed Res Int 2015: 897639.

Shuid, A.N., Chuan, L.H., Mohamed, N., Jaarin, K., Fong, Y.S., Soelaiman, I.N. 2007. Recycled palm oil is better than soy oil in maintaining bone properties in a menopausal syndrome model of ovariectomized rat. Asia Pac J Clin Nutr 16(3): 393-402.

Soelaiman, I.N., Ming, W., Abu Bakar, R., Hashnan, N.A., Mohd Ali, H., Mohamed, N., Muhammad, N., Shuid, A.N. 2012. Palm tocotrienol supplementation enhanced bone formation in oestrogen-deficient rats. Int J Endocrino/ 2012: 532862.

Vedi, S., Compston, J. 2003. Bone histomorphometry. Methods Mol Med 80: 283-298.

Weibel, E.R., Kistler G.S., Scherle, W.F. 1966. Practical stereological methods for morphometric cytology. J Cell Biol 30(1): 23-38. 